\title{
Gynecomastia in a Rheumatoid Arthritis Patient; a Rare Side Effect of Methotrexate Therapy
}

\author{
Soorih Shaikh, Sarwan Shaikh \\ The Indus Hospital, Karachi, Pakistan \\ Email: soorihaijaz@yahoo.com, sarwanaijaz29@gmail.com
}

Received 23 June 2016; accepted 25 July 2016; published 28 July 2016

Copyright (C) 2016 by authors and Scientific Research Publishing Inc.

This work is licensed under the Creative Commons Attribution International License (CC BY). http://creativecommons.org/licenses/by/4.0/

(c) (i) Open Access

\begin{abstract}
We are reporting a case of a 51-year-old male patient with 3-year history of Rheumatoid Arthritis who developed gynecomastia 2 - 3 months after starting Methotrexate (MTX) therapy, without folate supplementation. Two months after stopping MTX therapy and initiating folate supplementation, gynecomastia started resolving. Very few cases of gynecomastia due to MTX therapy have been reported worldwide, although it is a rare yet a significant occurrence and should always be considered in male patients with Rheumatoid Arthritis.
\end{abstract}

\section{Keywords}

Rheumatoid Arthritis, Gynecomastia, Methotrexate, Folate

\section{Case Report}

A 51-year-old male patient, with no known co-morbidities, came with complaint of painful progressive deformation of joints. Symptoms started 3 years ago with moderate to severe pain in the small joints of hands, wrist $\&$ ankle, morning stiffness for more than 45 minutes and decreased range of motion. Overtime, he noticed progressive deformation of the respective joints. On examination, he had deformed interphalangeal, wrist and ankle joints, bilaterally with marked ulnar deviation of wrist joints. Radiographs of both wrist and ankle joints showed osteopenia, decreased joint space and other features of Rheumatoid Arthritis (Figure 1). His lab studies showed positive RA factor (qualitatively and high-quantitatively) and Anti-CCP antibodies, confirming the severe course of RA.

On the basis of above findings, he was started on Naproxen (Synflex) $550 \mathrm{mg}$ once daily, Methotrexate (Imutrex) $10 \mathrm{mg}$ once weekly (without folate supplementation) and Calcium/Vitamin D supplements once daily; in response to the medications, joint deformation slowed down but he developed gynecomastia within a period of $2-3$ months. 


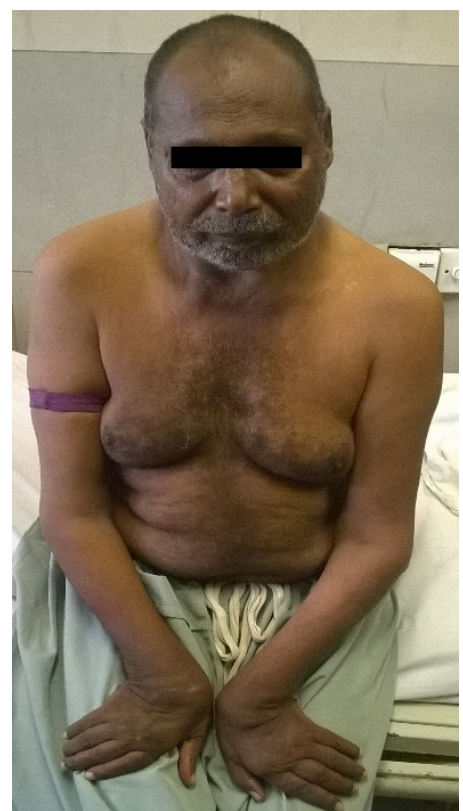

Figure 1. Gynecomastia and deformed wrist joints in a patient with rheumatoid arthritis.

This patient in particular was prescribed MTX therapy without folate supplementation, hence, he developed gynecomastia earlier as compared to previously known cases. A thorough work-up for gynecomastia was performed. It was found that the patient did not have any other co-morbidities that could lead to the development of gynecomastia, hence, MTX was considered to be the cause. So MTX therapy was discontinued and folate supplementation initiated. About 2 months after stopping MTX and starting folate, gynecomastia started to resolve.

\section{Discussion}

Rheumatoid arthritis (RA) is an autoimmune disorder characterized by chronic, progressive, inflammatory destruction of joint lining that results in erosion of bone and leading ultimately to the deformed joint. RA usually affects the small joints of hands and feet but large joints of body can also be affected. Although there is no cure for RA, multiple treatment options including NSAIDs, Steroids and DMARDs have been known to decrease symptoms, slow disease progression and significantly improve overall functioning.

Methotrexate (MTX) is the most commonly used drug in DMARD (Disease-Modifying Anti-Rheumatic Drugs) therapy. It is an anti-folate and antimetabolite drug; it inhibits the enzyme dihydrofolate reductase (DHFR) and enzymes involved in purine metabolism. MTX is used as a treatment for cancer, medical abortions (in ectopic pregnancy etc.) and Rheumatoid Arthritis. It is recommended to be taken once or twice a week only. MTX therapy, even in low doses [1]-[3] causes multiple side effects; Hepatic toxicity, bone marrow suppression, pneumonitis \& lung fibrosis, hypersensitivity and rarely gynecomastia and sexual dysfunction [4] [5].

Gynecomastia is a rare side effect of MTX therapy [1] [3] [6] [7]; so far, only 8 to 10 cases have been reported. Out of many proposed mechanisms for development of gynecomastia with methotrexate therapy, most supported yet unproven theory is, methotrexate being an antimetabolite drug damages leydig cells in testicles, leading to azoospermia and decreased testosterone production. This in turn stimulates Luteinizing hormone (LH) production which leads to increased production of estrogen from testicles, disturbing estrogen to testosterone ratio and formation of breast tissue in males.

Folate supplementation with MTX therapy is essential to reduce and delay the side effects [2]. It is seen that patients usually develop gynecomastia and other side effects when they skip folate therapy. In previously known cases, patients developed gynecomastia after about 3 - 4 months of MTX therapy (with folate supplementation), about a month or two later than this patient. This clearly shows MTX is the cause of developing gynecomastia and folate has an important delaying and preventing effect on development of gynecomastia caused by MTX therapy. It is also seen that gynecomastia caused by MTX is reversible; once Methotrexate is stopped and Folate supplements initiated, gynecomastia resolves itself. 


\section{Conclusion}

We suggest that folate should be prescribed as a part of methotrexate therapy in Rheumatoid Arthritis to lessen frequency and severity of the side effects. It is also suggested that further studies be conducted to understand the phenomenon behind development of gynecomastia with MTX therapy; it is MTX itself that causes gynecomastia or its chemotherapeutic effect that damages leydig cells leading to disturbed estrogen-testosterone ratio or its effect on liver that leads to decreased estrogen metabolism and development of gynecomastia.

\section{References}

[1] Abe, K., Mitsuka, T., Kanamori, S., Yamashita, K. and Yamaoka, A. (2007) Gynecomastia Associated with Low-Dose Methotrexate Therapy for Rheumatoid Arthritis. Modern Rheumatology, 17, 511-513. http://dx.doi.org/10.3109/s10165-007-0619-2

[2] Fukushi, J., Nakashima, Y. and Iwamoto, Y. (2010) Gynecomastia Associated with Low-Dose Methotrexate Therapy for Rheumatoid Arthritis Ameliorated by Folate Supplement. Rheumatology International, 30, 1371-1372. http://dx.doi.org/10.1007/s00296-009-1062-9

[3] Del Paine, D.W., Leek, J.C., Jakle, C. and Robbins, D.L. (1983) Gynecomastia Associated with Low-Dose Methotrexate Therapy. Arthritis \& Rheumatism, 26, 691-692. http://dx.doi.org/10.1002/art.1780260523

[4] Maria, A., Antonio, V., Manuel, R. and Eduardo, C. (2002) Gynecomastia and Sexual Impotence Associated with Methotrexate Treatment. The Journal of Rheumatology, 29, 1793-1794.

[5] Schmutz, J.L., Barbaud, A. and Techot, P. (2004) Gynecomastia and Sexual Disorders Induced by Methotrexate. Annales de Dermatologie et de Vénéréologie, 131, 1024. http://dx.doi.org/10.1016/S0151-9638(04)93826-4

[6] Thomas, E., Leroux, J.L. and Blotman, F. (1994) Gynecomastia in Patients with Rheumatoid Arthritis Treated with Methotrexate. The Journal of Rheumatology, 21, 1777-1778.

[7] Finger, D.R. and Klipple, G.L. (1995) Gynecomastia Following Low Dose Methotrexate Therapy for Rheumatoid Arthritis. The Journal of Rheumatology, 22, 796-797.

\section{Submit or recommend next manuscript to SCIRP and we will provide best service for you:}

Accepting pre-submission inquiries through Email, Facebook, LinkedIn, Twitter, etc.

A wide selection of journals (inclusive of 9 subjects, more than 200 journals)

Providing 24-hour high-quality service

User-friendly online submission system

Fair and swift peer-review system

Efficient typesetting and proofreading procedure

Display of the result of downloads and visits, as well as the number of cited articles

Maximum dissemination of your research work

Submit your manuscript at: http://papersubmission.scirp.org/ 